\title{
Community and City
}

\author{
Naples, Bagnoli: former Nato area
}

\section{Piscopo, Carmine ${ }^{1}$; Buonanno, Daniela ${ }^{2}$}

1. Associate Professor of Architectural and Urban Composition, University of Naples Federico II, Department of Architecture, Italy, Naples; Urban Planning Councilor, City Council of Naples, Italy, carmine.piscopo2@unina.it 2. Architect, PHD in Urban Design and Planning, University of Naples Federico II, Department of Architecture, Italy, Naples, buonannodaniela@gmail.com

\section{Resumen}

La observación de la complejidad de la realidad urbana, a través de una nueva sensibilidad por el medio ambiente, la naturaleza y la tierra, está gradualmente cambiando el sentido y el valor de algunas prácticas arquitectónicas y urbanas, tanto en el ámbito académico como en el institucional/político. De esta manera, se puede definir un nuevo tipo de paisaje urbano: el paisaje productivo; cuyo componente principal está representado por la tierra y el su valor multifuncional. Un intento de la idea fue puesto a prueba en la zona Nato en el oeste de Nápoles (Italia). Esta área fue ocupada por el ejército de los Estados Unidos durante 50 años. En 2013, el área fue finalmente liberada y, mediante un acuerdo con la ciudad de Nápoles (en la persona del alcalde Luigi de Magistris) y la fondación Banco di Napoli, lo que fue una vez un lugar donde se han decidido guerras, es ahora convertido en un lugar donde se crea la paz y la colectivización. El plano de un parque de naturaleza agrícola deriva de una demanda pública y de la participación activa de los ciudadanos que han promovido uso y administración de esta área. La realización de este proyecto para la ciudad de Nápoles es un ejemplo de cómo los intereses de los ciudadanos, las instituciones y los profesionales se pueden poner de acuerdo. De esta manera, los principios inspiradores de la "demostración de interés" se puede resumir en la siguiente manera: la identificación de un segmento de la población joven como el primer destinatario de la rehabilitación de la zona; la externalización de la función social del proyecto al fin de ser implementado en términos de: "recuperación de la cohesión social", "conformación de un habitat urbano autogestido de la comunidad de usuarios y residentes", "activación de procesos espontáneos entre los usuarios", "participación directa de los ciudadanos", soporte de las instituciones públicas y adopción del principio de la sostenibilidad ambiental.

Palabras clave: Reciclar, Recuperar, Red de contactos, Urbanismo Rural, Participación Directa

\begin{abstract}
The observation of urban reality complexity, through a new sensibility towards the environment, the nature and the earth, is slowly changing the sense and the value of some practices of architectural and urban acting, not only in the academia, but also in the institutional/politic field. In this way, it is possible to define a new kind of urban landscape, the productive landscape, whose main component is represented by the land and by its multi-functional value. A experimentation of the concept has been applied to the ex Nato area in west Naples (Italy). The area was occupied by the U.S. Army for 50 years. In 2013, it was finally freed, and through an agreement with the Municipality of Naples (in the person of the Mayor Luigi de Magistris) and the Banco di Napoli Foundation, what once was a place where wars were decided, today it becomes a place to build peace and sociality. The project of an agricultural natural park stems from a public demand and from the active participation of citizens that promoted the use and management of this area. The realization of this project for the Municipality of Naples is an example of how the interests of citizens, institutions and professionals can meet. Therefore, the guiding principles of Naples municipality "interest" can be summarized as follows: the identification of a young segment of the population as the first recipient of the area reuse, the expression of the social function of the project to be implemented in order of a recovery of social cohesion, a conformation of an urban self-governing community of users and residents, activation of spontaneous processes among the users, direct participation of the citizens, support of public institutions, adoption of environmental sustainability.
\end{abstract}

Key words: : Reclaiming, Regaining, Networking, Ruralurbanism, Direct Participation 
Innovación e Investigación en Arquitectura y Territorio. Departamento de Expresión Gráfica y Cartografía. Arquitectura. Escuela Politécnica Superior. Universidad de Alicante. №3 septiembre 2015 ISSN: 2341-0515

\section{Introduction.}

The integration of agricultural areas in urban spaces (ruralurbanism) is a topic of great interest, especially during the economic, social and environmental crisis that we are currently experiencing. The demand for food and food products continue to increase, while the fertile lands where it is possible to grow are becoming less and less, due to new buildings and an extremely intensive use of agricultural areas, that will eventually be impoverished to the point of becoming barren, some real deserts. Therefore, the contemporary urban project have to be able to detect and prevent, through specific responses in terms of planning, the effects of a radical change that will completely transform the way we live and perceive urban space. From these premises, there is a need to return to work on our projects with an old material, the earth, to transform potentially fertile urban areas in productive spaces, in terms of food production, but also economic, social and cultural production. The objective of the future will be to subtract the urban "voids" to the processes of traditional urbanization to turn them into habitable and arable landscapes, public space and productive space at the same time.

The velocity with which today the anthropological, economical and environmental dynamics, in their occurring and their continuous inter-relating, structurally change the urban setting, imposes the need to work in synergy between institutions, universities, professionals and citizens to build together a precise idea of city, an idea made of relationships, position values, democratic availability and concrete representation of community needs.

An idea intended to tie the landscape to the democratic right, overcoming that definition of landscape as a place of relationship and movement (Mouvance), or change (Mutation), to arrive - through the communities recognition to the sphere of membership and right.

The redesign project of the former NATO area in Naples and of the San Laise agricultural hill is just a small story of a Naples larger purpose, the purpose to work to overcome conflictual binomials such as open city versus closed city or network of urban public spaces versus "citadel", to precisely intervene in order to rebuild a link that has been too much often interrupted between architecture and society. This project uses terms such as inclusion, mending, networking, but there is also an integration between the city and the agriculture, the earth and the public space. The theme of ruralurbanism becomes a central thing to start reclaiming and regaining the Collegio Ciano spaces. This project starts from the San Laise hill, from its productive value and its ability to realize a fertile system that unites and creates new forms of community and works to improve the city and make it more sustainable.

Therefore the regeneration of the former NATO area and its agricultural spaces is the story of the return to the city of a denied space, of a space that has been forbidden to the community for very long time, of a productive space in Bagnoli, a neighborhood that has paid a high toll in terms of social spaces, housing policies, fight for the job, and protection of health and fundamental rights of life.

The transformation of the area (the disposal of the extra-territorial military function) marks the definitive fall of the "Iron Curtain" (Berlin Wall) in Naples and assumes a very important role in terms of urban meanings: once a place where historically wars were decided, a fundamental military base for numerous conflicts (Kuwait, Iraq, former Jugoslavia, Afghanistan), today the NATO area becomes a place to build peace and sociality (Figure 1).

We hope that the rebirth of Bagnoli will start from this historical moment: from the return of the Collegio spaces to the city, according to "bottom-up approaches" and through the firm and clear will of its inhabitants, its educational institutions, its social production centers and the city administration.

During the 2013, the city administration and the landowners have signed an innovative public-public Memorandum of Understanding that presents times, terms and conditions for the construction of a general master plan defined by the NATO Urban Implementation Plan.

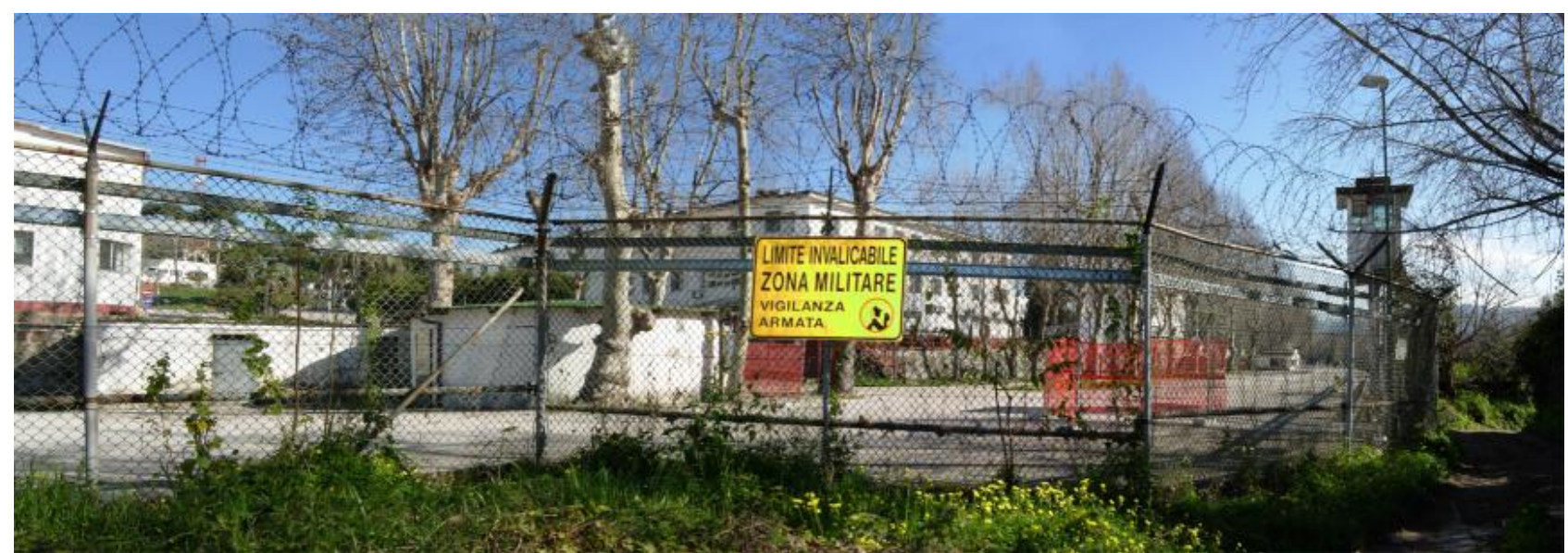

Figure 1. The barbed wire protecting the area is still visible today. The sign says: Military Security Zone. Entrance Forbidden. 
Innovación e Investigación en Arquitectura y Territorio. Departamento de Expresión Gráfica y Cartografía. Arquitectura. Escuela Politécnica Superior. Universidad de Alicante. Nㅜ3 septiembre 2015 ISSN: 2341-0515

\section{The history of Collegio Costanzo Ciano.}

The Collegio Costanzo Ciano was inaugurated in 1940, and at the time it was an absolute novelty in the field of social architecture, because it was intended to be a great hospitality center for children in need, and so it soon became the "Città degli Scugnizzi" (City of Street Urchins).

In fact, for its fourth centenary, The Banco di Napoli Foundation for Childcare (that is the owner of the land) built the Collegio as a model of hospitality and solidarity for the entire country, an open place for the city and the most needy. The area of about 20 hectares was organized like a real youth citadel with 18 buildings, schools, dormitories, infirmaries, logistic and sporting structures, a church, a theater, and it could host about 2500 boys and girls in need of hospitality (Figure 2).

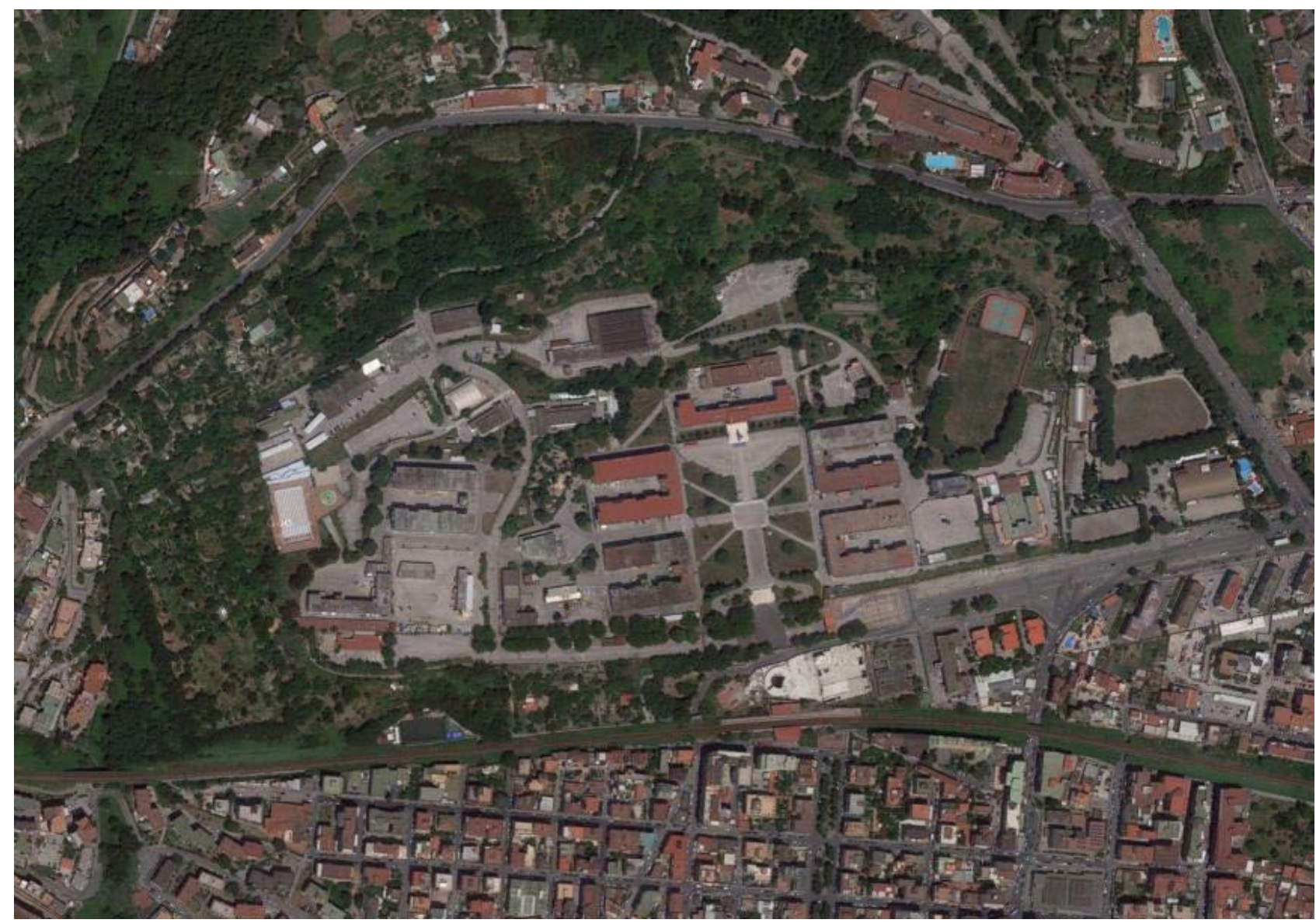

Figure 2. Satellite photo of Collegio Ciano and San Laise hill.

Unfortunately, this area suffered a completely opposite fate to the one for which it was built. In fact, just a few weeks after its inauguration, the 10th june of 1940 Italy went to war and the Collegio became the seat of ItalianGerman troops, and at the end of the war the Anglo-American troops took over it.

Then, for diplomatic issues and to maintain balance between nations, the Collegio was given under the lease to the Supreme Commander of NATO that remained there for over 50 years, until 2013.

Since then, the liberation of what was a real gated community (a defined and inaccessible zone, whose inhabitants enjoyed services and privileges guaranteed by the military forces) has created a long and fruitful debate on the future of these spaces and the surrounding lands. The hope is that they can return to be what they did not have the time to be: a place of social and civil development for the weakest part of the population (Figure 3). In particular the cultural and environmental development of the San Laise hill agricultural areas, committed to co-ops of citizens, could immediately create a system of urban vegetables gardens, connected with cultural initiative for leisure and youth accommodation, education and environmental testing. Indeed, the future of this territory is deeply rooted in its past and in its original agricultural nature. In fact, in the past, before the Collegio construction, the San Laise hill (between the Bagnoli neighborhood and the Pozzuoli hills) comprised many cultivated fields, and was exclusively inhabited by peasants, who lived within a large farmhouse, that was later demolished to build the Collegio. Once these lands were owned by the counts of Salluzzo of Corigliano, and later a part of them (about 30

Community and City. Naples, Bagnoli: former Nato area. Daniela Buonanno, Carmine Piscopo.

DOI 10.14198/i2.2015.03.07 
Innovación e Investigación en Arquitectura y Territorio. Departamento de Expresión Gráfica y Cartografía. Arquitectura. Escuela Politécnica Superior. Universidad de Alicante. №3 septiembre 2015 ISSN: 2341-0515

acres) was bought by the Banco di Napoli Foundation for Childcare, that used 20 hectares to build the Collegio, while the other 10 hectares remained intact as an agricultural area.
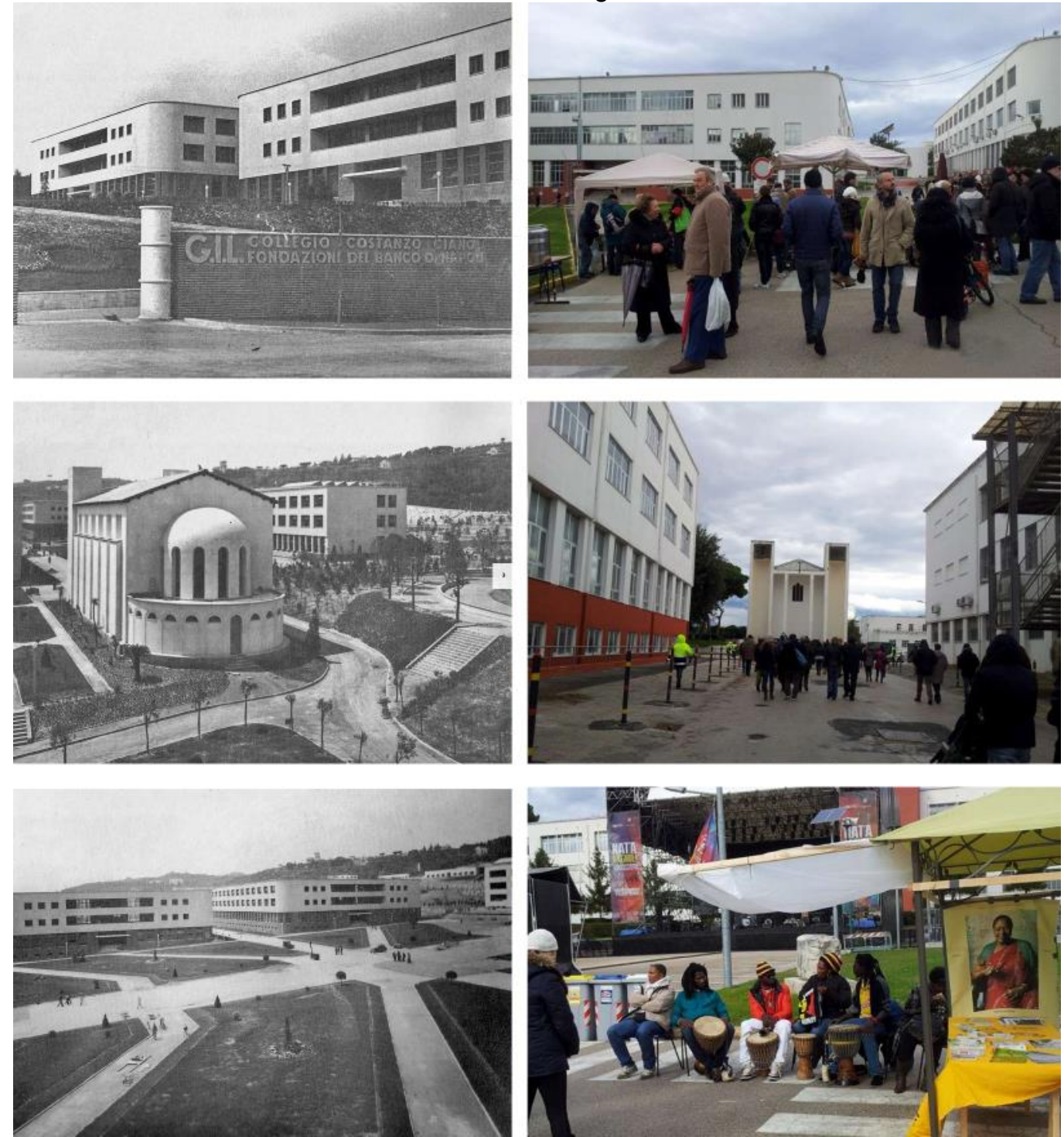

Figure 3. Historical photos and current photos of the Collegio. The citadel is repopulated and for the first time includes the city.

The Salluzzo kept about six acres, that longitudinally extended themselves on the left of the Collegio and where the old settlers remained continuing to pay the rent, even when these lands were sold - without their knowledge to a real estate based in Milan.

The story of San Laise hill and its peasants has largely remained unknown to the Naples citizens, and also its geography has been erased for a long time, because for the entire period of the American "occupation" even satellites could not provide documentary evidence of its existence.

Only because there have been some incidents of speculative nature, incidents that have outraged local citizens and associations, mass media have talked about this area for a few days, but then it has been forgotten again.

Even today, real estate is indeed very interested about these agricultural areas, where you can enjoy a spectacular view of Nisida, Posillipo and Capri.

In fact, the real estate that is still in possession of the lower part of the hill behind the subway is slowly evicting for speculative reasons the heirs of the original farming families who, however, have continued to cultivate these lands and to pay the rent for all this time. Trying to avoid this danger, thanks to the renewed interest of the institutions for the Collegio Ciano, and together with the direct involvement of citizens and associations (fundamental is the role of the Circolo Legambiente Thomas Sankara, especially in the figure of dr. Giovanni Grasso), today there are many projects that aim to raise awareness of a growing number of people and institutions (schools, universities etc.), in order to realize a dream and transform San Laise in an open and productive space for the entire city (Figure 4).

Community and City. Naples, Bagnoli: former Nato area. Daniela Buonanno, Carmine Piscopo.

DOI 10.14198/i2.2015.03.07 

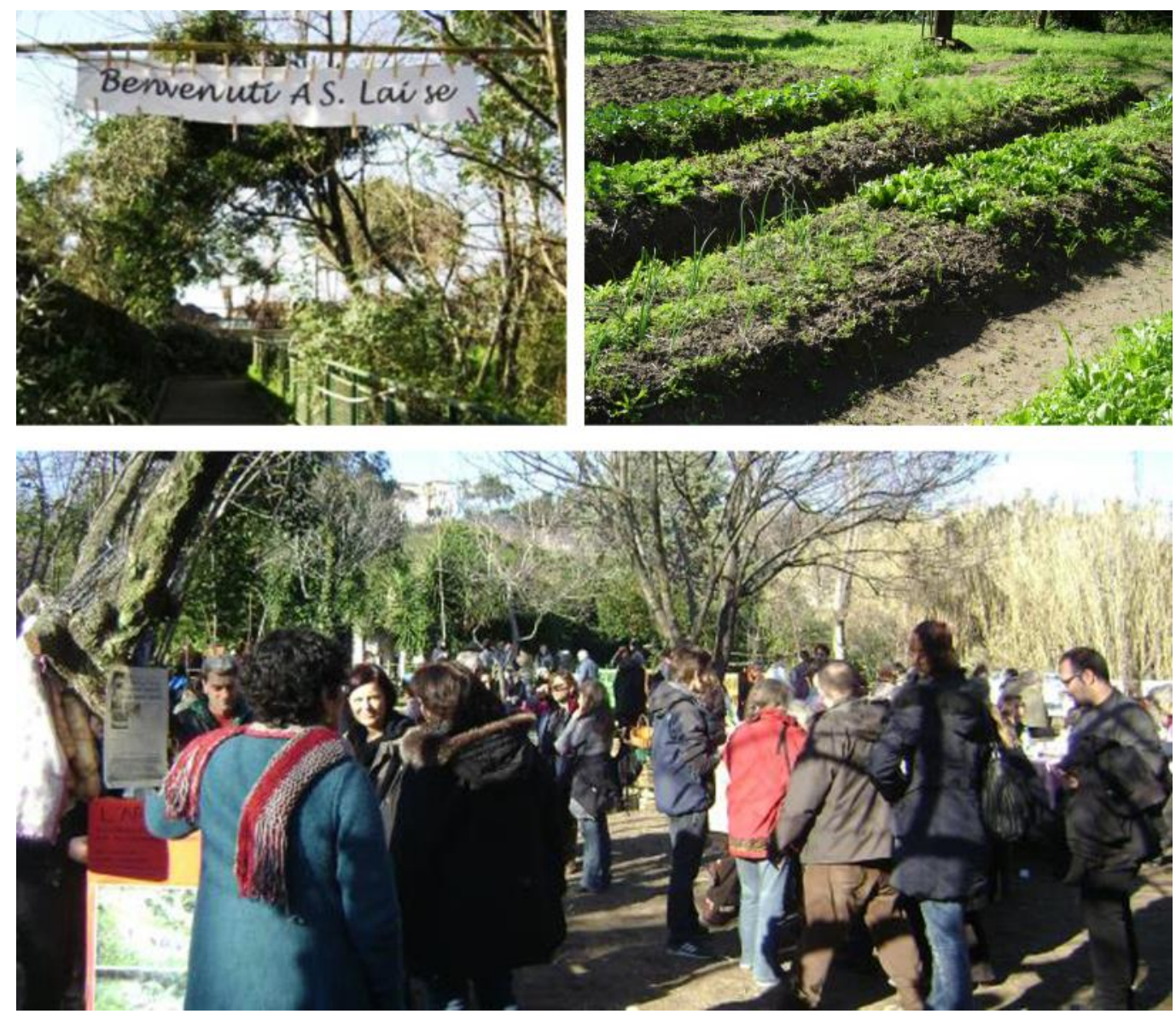

Figure 4 San Laise hill is agriculture, orchard, garden but also social relationships, entertainment, education, togetherness....

\section{Social initiatives.}

The liberation of the Collegio Ciano from NATO, along with the eviction notices that were being issued almost at the same time towards the early settlers of San Laise, has given rise to various public meetings where Bagnoli citizens have tried to decide by themselves the future of this area, and not leave it up only to the institutions.

The meetings, almost all self-organized, are always centered on the same mandatory request to the administration: to have the possibility to collectively and actively participate in the management of the reopening of the former NATO area.

These meetings emphasize the need to coordinate all the movements and the committees that are interested in the management of the Collegio and to find a shared solution, to avoid fragmentation and individualistic initiatives that do not have the strength then to revamp and repopulate the area.

The ideas on the reuse of the places depart from the analysis of infrastructural deficiencies and of neighborhood problems that could be partially solved, if the former NATO was given back to the community. We can start from the various schools of Phlegraean area, that are in an emergency situation and that could be transferred in the large spaces already presents in the area, in order to take advantage - along with all the other neighborhood inhabitants - of gyms, swimming pools and equipped public areas that were the strength of the NATO gated community. Then there are the large green areas of the San Laise hill, with an already existing agricivic community (Ingersoll, 2007) that could be supported by other associations that deal with organic farming, and so new spaces could be cultivated and managed also for cultural and educational purposes.

In this project, the agricultural theme becomes very important. By now, agriculture has a multifunctional value and it can lead to new and more established forms of sociality.

Citizens must actively participate to cultivate an agricultural area, and this participation makes every space more urban, and it responds to local needs and involves the weakest part of society.An increasing number of citizens could then begin to live a more complete experience of the area, an experience based on values of recreation, education, therapy, environmentalism, and change in this way the urban lifestyle, without departing from the city and their neighborhood. Nutrition becomes a very important issue within this cultural and social revolution.

The introduction of a more extended agricultural cultivation in the city (such as in San Laise) would allow citizens to establish a clearer and more direct contact with the food they eat and to strengthen the sense of belonging to 
Innovación e Investigación en Arquitectura y Territorio. Departamento de Expresión Gráfica y Cartografía. Arquitectura. Escuela Politécnica Superior. Universidad de Alicante. N3s septiembre 2015 ISSN: 2341-0515

the place where they live. Waldheim reflects on this attitude and call it agrarian urbanism (Waldheim, 2006), emphasizing the role of agriculture to define the urban form and imagining the coincidence of both activities, living and cultivating, in the constant search for contact points and compatibility elements.

The urban vegetable gardens can become a way to give back to Bagnoli citizens their space and their role, showing that the countryside is now "inside" the city and it is not something separate and external.

A vegetable garden is always a good thing that not only manages to revive abandoned or disused spaces of the city, but it is also and above all an expression of creativity and of a social and food need.

The natural and social value of a urban vegetable garden can be achieved only in the case of a well coordinated urban agriculture and if there is a collective work, the anarchic and individualistic vegetable garden hardly contributes to the birth of a "social network" (Ingersoll, 2007).

For all these reasons, the main objectives of the associations and of the citizen movements are simple and clear and can be summarized as follows: to bring back agriculture and farmers in those lands and protect them; to prevent the eviction of the farmers who are already there; to prohibit the building of new edifices in the twenty acres of private property that does not belong to the Banco di Napoli Foundation at the expense of cultivated soils.

In brief, the request is to work with a model that will make the neighborhood self-sufficient and that will be able to attract other communities, and to give priority to the children needs, supporting the destination for which the complex was originally designed and built, and the preservation and the increase of the already existing agricultural and territorial values.

\section{Memorandum of understanding.}

On the 4th of November 2013, it has been signed a Memorandum of Understanding between the Banco di Napoli Foundation for Childcare and the City of Naples (in the person of the Mayor Luigi de Magistris), and this is the formal act by which administration points out the shared determination to return to the city the original social function of the former Collegio Ciano, recovering its public usability and reintegrating it into the urban life relationships, according to the urban predictions of the variant to the Local Strategic Plan for the west area of the city. The public-public agreement between administrations (the Banco di Napoli Foundation and the municipality of Naples) belongs to a broader pilot project that the municipal administration intends to promote and that includes, besides the San Laise hill, also the urban redevelopment of Viale Giochi del Mediterraneo, a strategic link between the neighborhoods of Bagnoli and Fuorigrotta, in particular through the connection of former NATO area with Mostra d'Oltremare places, that - according to a new urban program - have been recently opened for the community (Figure 5).

The particular environmental and social context of the settlement allows to experiment innovative forms of urban management, inspired by environmental sustainability and the direct participation of citizens. For this reason the main objective of the agreement, part of an integrated solution, is to give a (public) space and a place to activities that are primarily aimed at young people, and that focus on education, research, culture, sport, leisure, and youth accommodation capacity.

Therefore, the guiding principles of Naples municipality "interest" for the use of the property once occupied by NATO, can be summarized as follows: the identification of a young segment of the population as the first recipient of the area reuse, the expression of the social function of the project to be implemented in order of a "recovery of social cohesion", a "conformation of an urban self-governing community of users and residents", "activation of spontaneous processes among the users", "direct participation of the citizens", support of public institutions, adoption of environmental sustainability.

The various initiatives and projects should therefore, according to the indications of the municipality, be presented as a brave and innovative experiment of territorial planning, able to understand the local conditions, the most evident needs of the territory, in the present and in the future, and its ability of endurance towards economic and social transformations. At the heart of the project there must be three key issues: work and production, selfsufficiency and reproducibility, wide and collective participation.

The municipality of Naples intends to realize a real place of production in this territory, more precisely a selfsustainable and environmentally friendly place, an economically alternative place, an experimental place for the involved subjects, the carried out practices, and the technical instrument and legal ruling adopted. 

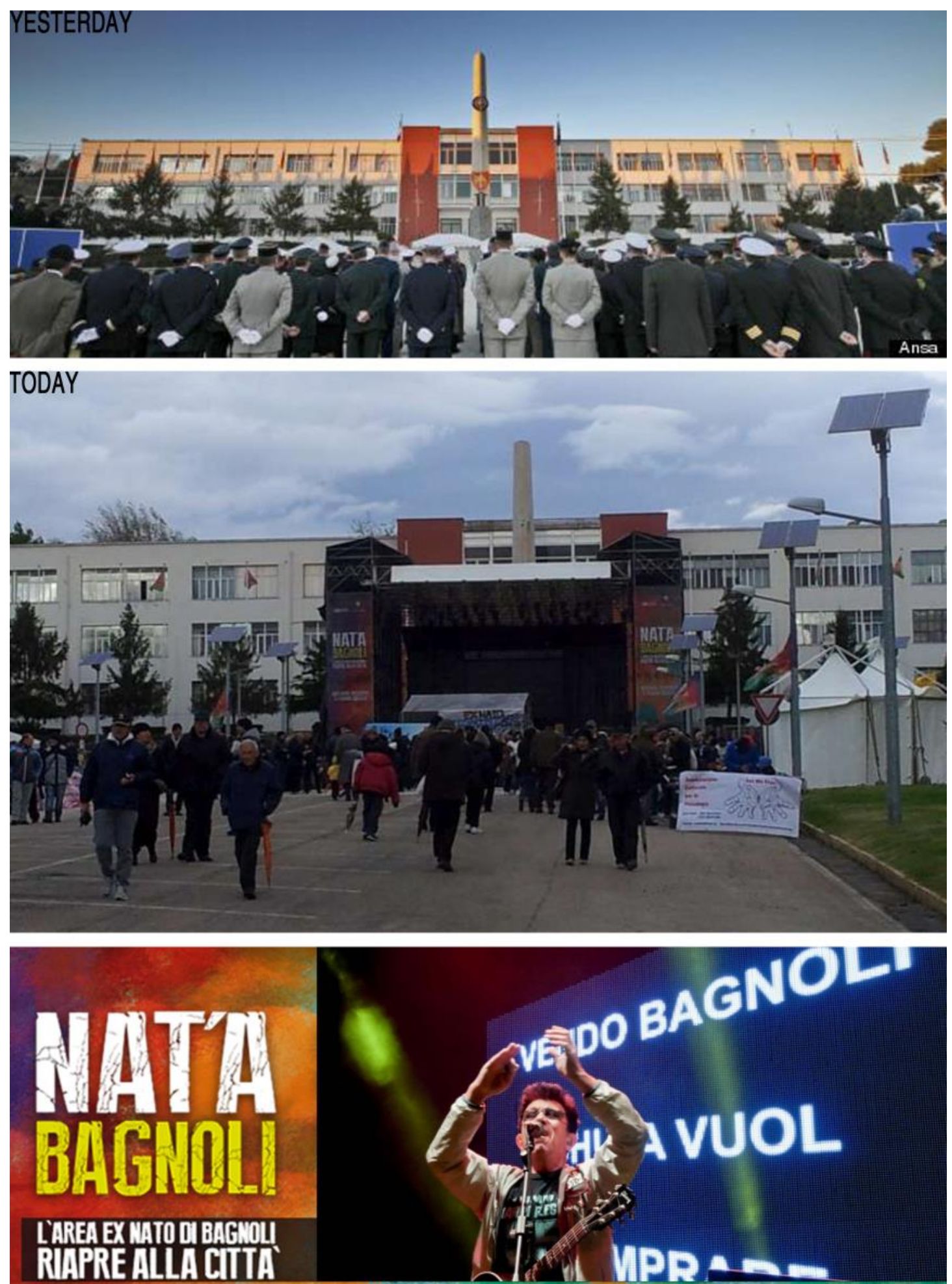

Figure 5. Yesterday there were the army, today the citizens. Break the lines and dance: on December the $1^{\text {st }}$, the "liberation" of the area was celebrated with a free public concert opened to all citizens.

\section{The project for the San Laise hill.}

A first step in the direction of the community demands and the Protocol principles has been made developing a project to enhance the natural value of the San Laise hill (Figure 6).

The project, that at the moment is being developed and then will be implemented, imagines the immediate realization of social and educational vegetable gardens and anything else that is compatible with the agricultural use of the area, and these vegetable gardens will be given to citizens co-ops and will be managed together with schools

Community and City. Naples, Bagnoli: former Nato area. Daniela Buonanno, Carmine Piscopo. 
Innovación e Investigación en Arquitectura y Territorio. Departamento de Expresión Gráfica y Cartografía. Arquitectura. Escuela Politécnica Superior. Universidad de Alicante. Nㅜ3 septiembre 2015 ISSN: 2341-0515

and universities.

In this way it will be assured a social income to the weaker part of the population through the opening of the neighborhood and its agricultural spaces, and this part of the population will enjoy free local services (educational activities, sports, libraries, workshops, theatrical activities, schools, etc. ..). The project, directed by Dario Caruso, Gianni Grasso and the architect Salvatore Porcaro, considering the difficulty of realization because of the different private properties of the area and the involved subjects, is divided in three phases with different timing and mode of realization. Phase 1 concerns the agricultural areas that still belong to the Foundation (10 hectares) and that could be immediately transformed into an agricultural natural park; in phase 2 this area will be reconnected to Collegio Ciano, in order to reconfigure a sort of continuity between these two areas that for 60 years have been divided by a barbed wire; the phase 3 is the most complex and concerns the areas owned by the SIMIT - Società Immobiliare Italiana SPA (Real Estate Company Italian SPA) - that now have been sold to ICG - Ingegneria e Costruzioni Generali SPA (Engineering and General Constructions SPA), for which the project aims to protect and preserve the existing agricultural activity in order to reconnect with the park system of phase 1 and to prevent any form of speculation in the future (Figure 7). Compared to the agricultural natural park, that should be born in the area owned by the Banco di Napoli Foundation and therefore easy to realize, the planned project is built around four highly integrated themes: nature - agriculture - culture - teaching. The heart of the project is characterized by the productivity of the area, productivity that will be enhanced through the realization of social vegetable gardens whose objective will be to generate new forms of culture and teaching, and to encourage the direct relationship between producer and consumer with innovative forms of co-operation and management also through the support of the Federico II University Department of Agriculture and/or local schools (with whom meetings have already been held).
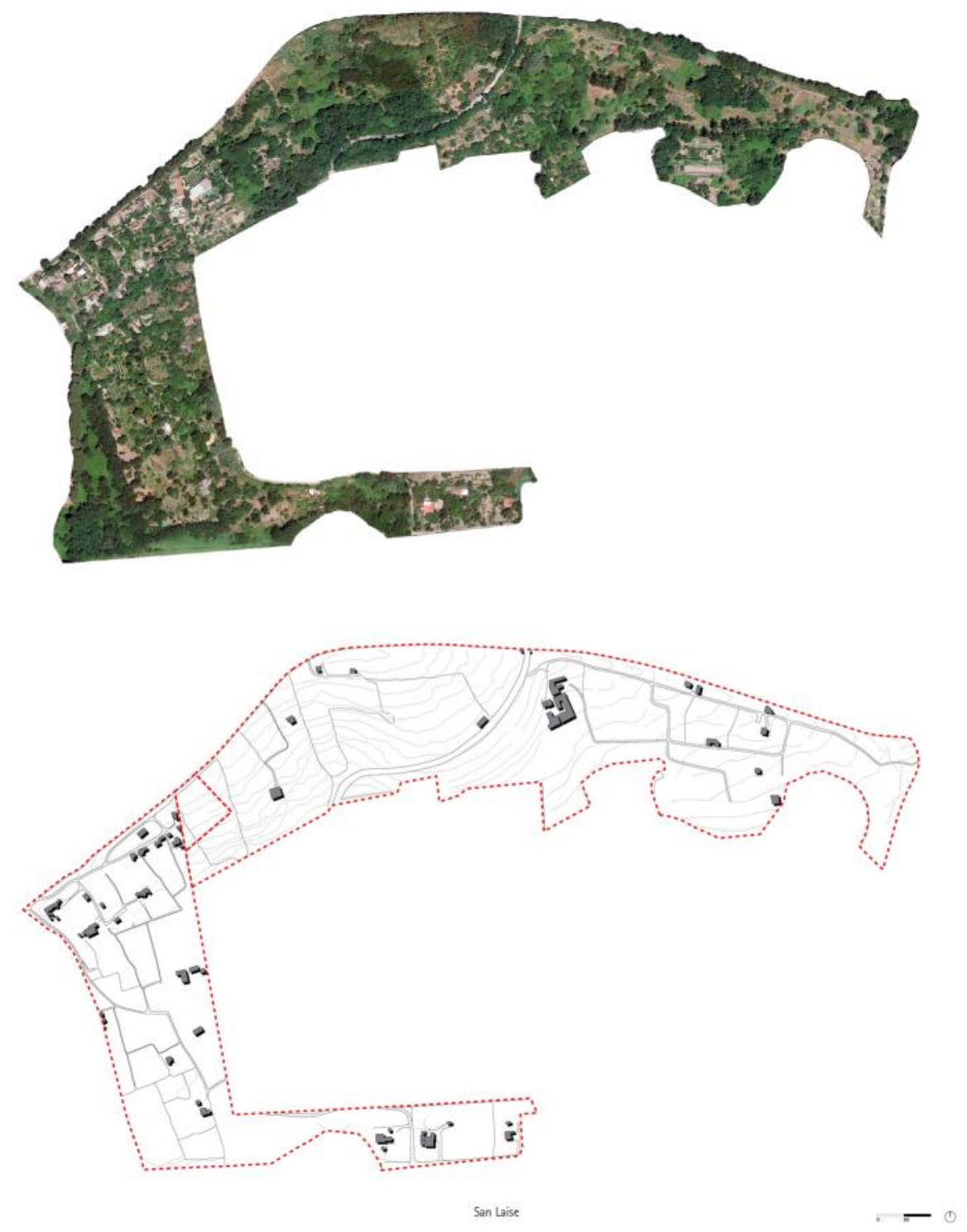

Community and City. Naples, Bagnoli: former Nato area. Daniela Buonanno, Carmine Piscopo.

DOI 10.14198/i2.2015.03.07 
Innovación e Investigación en Arquitectura y Territorio. Departamento de Expresión Gráfica y Cartografía. Arquitectura. Escuela Politécnica Superior. Universidad de Alicante. №3 septiembre 2015 ISSN: 2341-0515

Figure 6. Satellite photo and dwg map of San Laise hill and its buildings. Drawings by Arch. S. Porcaro
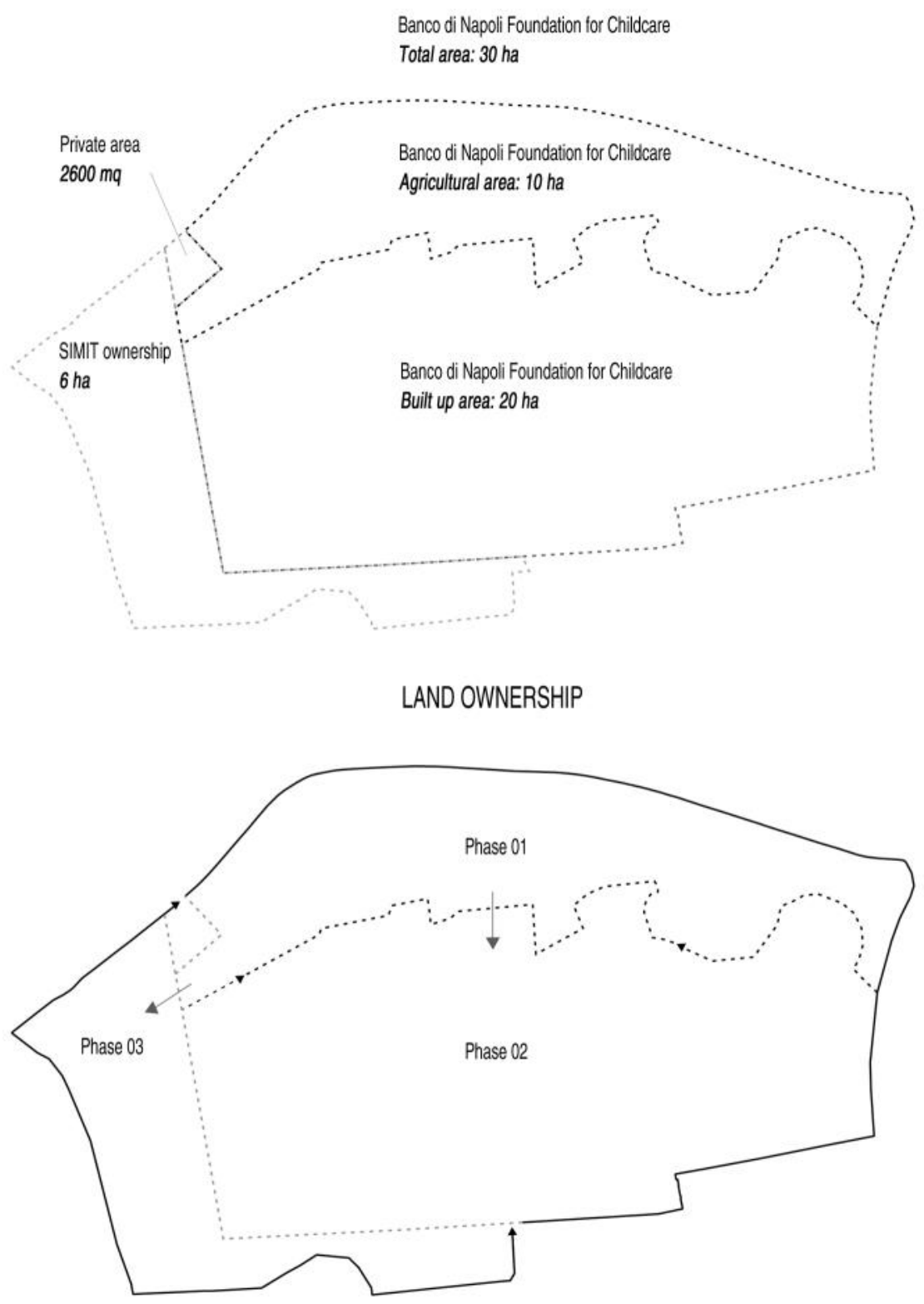

PROJECT PHASES

Figure 7. San Laise hill: land ownership map and project phases. Drawings by Arch. S. Porcaro

Agricultural production can be connected with the city markets through a system of short chain, like it already happens in other areas of Naples.

So the preservation and protection of rural territory is intertwined with the defense of the agriculture economic function and at the same time answers to the urban community demand of open spaces characterized by significant cultural values and the possibility of new forms of consumption.

For this reason, the project considers the construction of small markets, an agricultural research center and a museum of farming culture, in which will be also realized a bank of seeds. If this project will be realized, because of its geographical position, from the agricultural park of San Laise could rise a continuous system of productive fields, and it would become a connecting element between the park of the Naples hills (east) and Campi Flegrei Park (west). But, however, the greatest value is on local scale. For the Bagnoli neighborhood San Laise would be the first real public park, and it would have a strong social function for the residents of the area, that now resembles a small citadel closed on the north by the metro line (north) and on the west by the Cumana railway. The

Community and City. Naples, Bagnoli: former Nato area. Daniela Buonanno, Carmine Piscopo.

DOI 10.14198/i2.2015.03.07 
Innovación e Investigación en Arquitectura y Territorio. Departamento de Expresión Gráfica y Cartografía. Arquitectura. Escuela Politécnica Superior. Universidad de Alicante. №3 septiembre 2015 ISSN: 2341-0515

opening of the Collegio Ciano, with the definition of a general master plan with the various destinations of use (based on the expressions of interest received by the Foundation), and the transfer of standard and equipment of the neighborhood (objective of phase 2), would also create new connections with the urban area of Fuorigrotta and Mostra d'Oltremare, regenerating Viale Giochi del Mediterraneo, which could become a well equipped axis that links public spaces, entertainment places, cinema, sports arenas. In this way, for Naples, the recovery of former NATO area may represent an important opportunity to give back to the community and to its weakest and needy part a space that has been denied and prohibited for too long. Therefore, in a highly complex context, the City of Naples has decided that the Bagnoli rebirth has to start from an experiment of re-appropriation, according to "bottom-up" approaches, a thing that in a very near future will hopefully also concern the former Italsider area in which a new environmental and natural system is just waiting to be realized.

\section{Conclusions.}

The re-functionalization of the former Collegio Ciano and of the San Laise hill represents an unmissable opportunity for Naples. To realize this thing, the project must be very well structured, and a good capacity of organization and participation is needed.

The actual decision-making phase is absolutely crucial in order to build a serious program of things to do and to better manage a large resource of tangible and intangible (ideas, skills, competencies) goods.

Given the total military secrecy of the places we are talking about, after the departure of the American army the first thing has been to reconstruct the framework of the events related to the

management of the area through a phase of preliminary investigation, an investigation that has led to focus on involved subjects and roles, collect documents (contracts, protocols, statutes, etc.) and quantitative and qualitative data related to these areas and the state of the real estate and the agricultural lands. Now, we need to manage to realize the many ideas and proposals received, verifying the access to resources, identifying the methods for democratic participation and how they are in confront of the resolutions proposed to the Council, and defining priorities and timing of the project.

In fact, as we have seen, the San Laise hill project is structured in three phases for this reason. As for the reuse of the former Collegio Ciano spaces, the project should be coherent, in terms of functions, with the idea of a productive area.

In other words, the project should not privilege those functions that simply concern consumption or the filling of containers ("urban voids") that suddenly become available, but those functions that concern the integration of urban services, on the basis of the transfer and the intertwine of knowledge and skills.

In addition of educational institutions (this is a priority) and structures for youth accommodation (dormitories and student residences), it would be necessary to create the conditions for the settlement of trades and professions, to build training and internship courses, to experiment co-working forms, to build opportunities for visibility, to start an administrative streamlining, to make use of cultural functions in order to produce culture (to publish things not just build libraries, to produce music not just organize concerts, to create audio-visual products not just exhibitions, to produce information not just consume it).

However, these production forms described above must not be self-organized, on the contrary they must be planned and integrated into a program that must be arranged between citizens and institutions. The awareness of the scarcity of local economic resources, public and private, as well as the possibility that Europeans funds are not immediately manageable, requires that from the start the project could be autonomously developed, integrating functions and relationships. Of utmost importance is also the legal and technical reproducibility of all the identified activities and instruments, in order to rapidly proceed on other occasions, albeit there will be some differences.

In this sense, the natural regeneration of San Laise hill, defending the economic function of agriculture, could be considered as a pilot project that can be also proposed in other agricultural areas of the municipal area and for which new forms of equal distribution can be experimented. With these methods there is the condemnation of the self-referential planning and of every abstract form of urban hypothesis that is not based on direct participation and on the democratic right to the use of public space, a place of expression of community genuine needs, and of production of new lifestyles and economies.

\section{Bibliography.}

Agnoletto, M.; Guarzoni, M., La campagna necessaria. Un'agenda d'intervento dopo l'esplosione urbana. Macerata: Quodlibet Studio, 2012.

Boeri, S., Biomilano, glossario si idee per una metropoli della biodiversità. Mantova: Corraini edizioni, 2011.

Buonanno, D., Ruralurbanism. Paesaggi Produttivi. Napoli: Phd thesis in Urban Design and planning, 2014.

Donadieu, P., Campagnes urbaines. Actes sud, 1998.

Ingersoll, R.; Fucci, B.; Sassatelli, M., AGRICivismo. Agricoltura urbana per la riqualificazione del paesaggio. (Linee guida e buone pratiche per l'agricoltura urbana). Progetto pays.doc, 2007. 
Innovación e Investigación en Arquitectura y Territorio. Departamento de Expresión Gráfica y Cartografía. Arquitectura. Escuela Politécnica Superior. Universidad de Alicante. №3 septiembre 2015 ISSN: 2341-0515

Koolhaas, R.; Boeri, S.; Kwinter, S.; Tazi, N., Mutation. Barcellona, 2001.

Nicolin, P., II bello dell'agricoltura urbana. In Urban Orchard, Lotus 149, 2012.

Lassus, B.; Berque, A.; Donadieu, P.; Conan, M.; Roger, A., Mouvance. Paris, 1999.

Piscopo, C., La città, macchina desiderante. Roma: Officina edizioni, 2012.

Waldheim, C., The Landascape urbanism. New York: Princeton Architectural Press, 2006. 